\title{
A SZAKÉRTŐVÉ VÁLÁS, ILLETVE A SZAKÉRTŐK KIVÁLASZTÁSÁNAK ÉS MEGKÉRDEZÉSÉNEK MÓDSZERTANI KIHÍVÁSAI
}

A szerző által tanulmányozott, szakértőkkel foglalkozó szakirodalom jelentős része a szakértőkkel történő szakmai munkára, a különböző csoportmódszerek bemutatására fókuszál, de a szakértővé válás folyamatával nem, vagy csak érintőlegesen foglalkozik. Ez a felismerés adta az alapötletet, hogy tanulmányában egy saját vizsgálódásra alapozva a szakértő kiválasztása és a megkérdezés módszertani kérdései mellett a szakértővé válás lehetőségeit, illetve a fogalom különböző kontextusban történő értelmezhetőségét is bemutassa. A szakmai szolgáltatások rövid ismertetése után a tanulmány első részében a szakértővé válás lehetőségeivel foglalkozik egy, a közelmúltban végzett saját információgyűjtés és annak feldolgozása során kapott eredmények közlésével. Megállapította, hogy Magyarországon jelenleg kilencféle módon lehet valaki szakértő, több esetben úgy, hogy a nem hivatalos szakértői minősítéssel rendelkező (szakmai) szolgáltatók egy része is végez, illetve felkérésre folytathat szakértői tevékenységet. A szakértői kiválasztás folyamatának bemutatásakor ismerteti a szakértői csoport létrehozásának feladatait, a szakértői kompetenciák meghatározásának módszereit. A tanulmány harmadik részében a szakértői megkérdezés módszerei közül tizenhetet mutat be, elsősorban a nevezett vizsgálódás szakértői interjúalanyainak véleménye alapján, zárásként pedig a szakértőkkel való munka továbbgondolására ad konkluzív jelleggel néhány tanácsot.*

\section{Kulcsszavak: szakmai szolgáltatások, szakértővé válás, szakértői kiválasztás, szakértői megkérdezés}

\section{Bevezetés}

A szakmai szolgáltatások körébe megannyi tevékenység tartozik bele a hétköznapi életben, az üzleti területen azonban ez a szám végesnek tekinthetö, s leggyakrabban az alábbi tevékenységeket értjük alatta: coaching, facilitáció, mediáció, mentorálás, szakértői tevékenység, szupervízió, tanácsadás, tréning. A szakértő - a Magyar nyelv értelmező szótára szerint - alaposan ért valamihez, ebben szerzett szakértelme átlagon felüli, s akinek véleményét szakmai kérdésekben ki szokták kérni. A szakértőről általánosságban azt mondhatjuk (vizsgálódásomban ezt a képet szeretném árnyalni), hogy rendszerint egy adott területen igazolható végzettséggel, gyakorlattal, bizonyos esetekben a törvényi előírásoknak megfelelő minősítéssel/ jogosítvánnyal rendelkezik (pl.: igazságügyi szakértő), vagy valamely szakmai szervezet/szövetség (pl.: Magyar Marketing Szövetség) engedélyezi a számára a szakmai szervezet szakértője cím használatát tevékenysége során. A szakértő általában írásos formában készíti el szakértői véleményét a rendelkezésére álló adatok és információk alapján. Tevékenységével természetesen hozzá tud járulni egy szervezet fejlődéséhez, de általában nem jellemző rá, hogy komolyabb párbeszédet folytasson a megbízójával. A szakértő szakértelme mint fogalom, tartalmában folyamatosan változik, egyrészt azért, mert a technika és a tudomány folyamatos ismeretekkel bővül, másrészt, mert azzal, hogy bizonyos ismeretek és tudások általános tudássá válnak, ki is esnek a szakértelem/speciális tudás köréből (Hengl, 2015). A tanácsadó (Poór, 2016; Block,
2005) a szakértőhöz hasonlóan rendszerint megfelelő végzettséggel és gyakorlattal rendelkezik, s minősítésében ugyancsak részt vesznek bizonyos hazai és nemzetközi szervezetek, de tevékenységét a törvényi kivételektől eltekintve (pl.: pszichológiai tanácsadó) szabadabban végezheti. A tanácsadó és a megbízó (vagy annak képviselője/ képviselöi) között rendszerint párbeszéd alakul ki, s a csoport részeként és aktív tagjaként (nem egyszer ad hoc jelleggel választott projektvezetőként) a csoporttal közösen keresik a megoldást a problémára. A tanácsadó saját szakterületének számos technikáját, modelljét, módszerét ismeri, így a megoldási alternatívák és lehetőségek felvázolásában, vagy akár a megoldás megkeresésében tud hatékonyan segíteni. Ez utóbbi hasonlít a coachhoz (Zelina, 2013; Kelló, 2014; Kaweh, 2017), aki akár a magán, akár az üzleti életben segíti a megbízóját céljai elérésében úgy, hogy elsősorban kérdéseket tesz fel, tehát a szakértővel és a hagyományos tanácsadóval szemben általában nem fogalmaz meg konkrét javaslatokat, inkább csak ,terelget” a megoldás, a célok felé. A coach tevékenysége lehet személyközi, illetve csoportos is, ez utóbbi hasonlóságot mutat a tréninggel. A felkészült tréner (Dürrschmidt et al., 2008) segítségével a csapat az előre megbeszélt célok és/ vagy kompetenciák elérésén dolgozik úgy, hogy hol komoly, hol vicces feladatokat oldanak meg a csoporttagok. Két személy közötti, vagy csoporton belüli folyamatok és megbeszélések eredményesebbé tételében nyújt segítséget a facilitátor (Kaner, 2014; Csemáné - Gilányi, 2011), aki nem szól bele a tartalomba, de biztosítja a barátságos, megoldásorientált légkört, a résztvevők egyenlőségét, s

“A mü a KÖFOP-2.1.2-VEKOP-15-2016-00001 azonosítószámú, „A jó kormányzást megalapozó közszolgálat-fejlesztés” elnevezésü kiemelt projekt keretében müködtetett Zrínyi Miklós Habilitációs Program keretében, a Nemzeti Közszolgálati Egyetem felkérésére készült. 
a kommunikációs és müködési szabályok betartását. Tevékenysége hasonlít a mediátorhoz (akinek közvetítői tevékenységét jogszabály határozza meg), de a mediátor (Ábrahám - Eörsi, 2003; Strasser - Randolph, 2008) a mediációs üléseknek egy feszesebb keretet ad. Az egymással konfliktusban levő felek problémamegoldó folyamatában vállal aktív szerepet a mediátor azáltal, hogy segít tisztázni a konfliktus természetét (az okokat rendszerint nem kutatja), illetve segíti a feleket, hogy egy egymást tisztelő dialógus során elmondják saját álláspontjukat, s türelmesen meghallgassák a másikét, majd egy mindkettőjük számára elfogadható megoldás szülessen. Előfordul, hogy a trénerek, tanácsadók, mediátorok, coachok stb. elakadnak, s külsős segítséghez, szupervízorhoz (Bagdy - Wiesner, 2005) fordulnak. Az elakadás oka rendszerint három dimenzióban értelmezhető: (1) elakadás az adott ügyben, (2) elakadás az adott módszer használatában és (3) elakadás a saját szakmai fejlődésben, esetleg a kiégés tüneteinek a megjelenése. A - kevesebb tapasztattal rendelkezö szakmai szolgáltatókat, a fiatalabb munkavállalókat, vagy a kezdő vállalkozókat mentor (Holliday, 2001) is segítheti. A mentor az a saját szakterületén tapasztalt és rendszerint elismert szakember, aki nincs alá-fölé rendeltségi viszonyban a mentorálttal, s tanácsaival, javaslataival többek között az indulásnál, a beilleszkedésnél, egy feladat megoldásában, vagy a szakmai fejlödésben tudja támogatni a mentoráltat, vagy idegen kifejezéssel a mentee-t.

Előfordul, a szakértő és a tanácsadó fogalma, illetve fogalmi kerete átfedi egymást. Fejes (2015) az Amerikai Vezetési Tanácsadó Mérnökök Egyesületének (ACME) definícióját citálja, miszerint ,a vállalati tanácsadás egy olyan professzionális szakmai szolgáltatás, amit speciális képzettségü, megfelelő szakmai tapasztalatokkal rendelkező szakértők végeznek", tehát a szakértő ebből az aspektusból tanácsadó munkát (is) végez. Tokár-Szadai (2013) véleménye szerint a ,szakértői szerepben (resource consulting) a tanácsadók speciális tudásukkal, tapasztalatukkal segítenek: információt szereznek, elemeznek, megoldásokat javasolnak, meggyőzik az ügyfelet ennek helyességéről”, vagyis a tanácsadók szakértői munkát végeznek.

A továbbiakban a fent általánosságban megfogalmazott szakértői tipizálás differenciáltabb képét vázolom fel.

\section{A szakértővé válás lehetőségei}

2017 első negyedévében egy három hónapon keresztül tartó felmérést végeztem arról, hogy Magyarországon jelenleg kit neveznek, illetve ki tekinti magát szakértőnek, a fogalom hogyan értelmezhetö, illetve hogyan értelmeződik a különböző kontextusokban. Számomra azért volt fontos ennek tisztázása, mivel a módszertani, vagy módszertannal is foglalkozó szakirodalom (pl.: Babbie, 2000) többsége vagy tényként kezeli a szakértők bevonását a kutatásba/ismeretalkotásba, vagy csak a konkrét kutatási módszernél (pl.: Delphi-módszer) utal arra, hogy milyen elvek mentén célszerü a szakértői csoportot összeállítani: „Előnyös az is, ha a szakértő ért a vizsgált problémához” (Kindler et al., 1984). Módszertanilag dokumentum-, illetve tartalomelemzést végeztem (amely elméleti alapozá- sára Krippendorff, 1995; Langer, 2009; Horváth - Mitev, 2015 szolgáltak), illetve 27 szakértővel telefonon/személyesen is felvettem a kapcsolatot, közülük 13 föt személyesen is meglátogattam. A tartalomelemzési mintavételi eljárások közül a klaszteres mintavételt, s azon belül a kvázi véletlen mintavételt választottam. Ez a gyakorlatban azt jelentette, hogy a Google és a felvi.hu keresőablakába a „szakértő" fogalmat beírva képeztem a szakértő, mint fogalom tartalmi klaszterét, mely kiegészült a saját ismeretségi körömben tevékenykedő szakértőkkel, egyetemek és képző intézmények, állami szervezetek és NGO-k weboldalaival, majd a klaszteren belül kvázi véletlen mintavételt végeztem, vagyis a keresőtalálatok, a weboldalak és saját ismerőseim között böngésztem. A célom az volt, hogy olyan, egymástól jól elkülöníthető fogalmi csoportokat képezzek, amelyekbe a szakértők beletartozhatnak. Természetesen - ahogy majd látni fogjuk - a csoportok között átjárás van, mégis úgy gondolom, hogy megnevezésük kellő hangsúllyal definiálja az egyes csoportokat. Megállapítottam, hogy jelenleg Magyarországon $8+1$ féle módon lehet valaki szakértö:

1. annak mondja magát,

2. a média mondja annak,

3. a megbízó, munkaadó „minősíti” annak,

4. olyan végzettséget szerez, amelyik nevében a szakértő kifejezés megtalálható,

5. valamelyik szakmai szövetség/szervezet/kamara minősíti,

6. szakmai/nonprofit szervezetben dolgozik szakértői munkakörben,

7. (kormányzati) szakértői intézetben dolgozik szakértői munkakörben,

8. megfelel a törvényben/rendeletben meghatározott elvárásoknak, s kérelmét az adott hatóság elfogadta és neve szerepel a szakértői névjegyzékben,

9. a kutató minősíti annak.

(1) Önjelölt szakértő bárki lehet. Egy tehetségesebb és intelligensebb szélhámos viszonylag könnyen el tudja készíttetni személyes márkáját, $\mathrm{s}$ annak részeként a (hamis) referenciákat tartalmazó weboldalát. A weboldalon megtalálható többek között a külföldi szakmai szervezetek minősítő okleveleinek a hamis másolata, illetve a híres/ befolyásos emberekkel készített közös fényképek is. Az ilyen „szakértők” névjegykártyája inspiráló, személyes megjelenése kifogástalan, modora megnyerő, stílusa választékos. Jobb esetben egy elegáns irodaházban irodát tud bérelni, s titkárnőt foglalkoztat. A róla szóló narratívumokban a „szakértő úr/asszony” kifejezés gyakran szerepel. Mivel a róla szóló összkép harmonikus, az egyes vizuális és textuális elemek kongruálnak egymással, így rendszerint kicsi az esélye annak, hogy lebukjon.

A (2) média által szakértőnek nevezett szakmai szolgáltató (a fogalom hétköznapi használata) megszólaltatása azon a médiamüködési elven alapul, hogy a médiamunkások szeretnének az előzetesen megtervezett és szerkesztett tartalmi kerethez minél több olyan tényt felsorakoztatni, amelyik megerősíti, hihetőbbé és hitelesebbé teszi a témát, 
illetve az arról nyilatkozókat. A reggeli/délelőtti beszélgetős müsorok témakínálatának felkonferálásakor gyakran hangzik el a „meghívott szakértőnk” szófordulat, de a hírmüsoroktól sem idegen a szakértők megkérdezése. A szexológusok, a pszichológusok, az orvosok, a biztonságpolitikával foglalkozó szakemberek, az informatikai és információbiztonsági szakemberek, a dietetikusok, az önvédelmi instruktorok, a politológusok, a fiatalokkal foglalkozó pedagógus és egyéb szakemberek, az etikettés protokoll-szakemberek, a spiritualitással, ezotériával foglalkozók, az asztrológusok stb. egyaránt a média által minősített szakértők közé sorolhatók. A szakértő mint címke használatával is jelzi a média, hogy tőle független véleménynek ad hangot.

Vannak olyan esetek, amikor a (3) megbízó „,minösit'” szakértönek valakit. Ez rendszerint akkor következik be, amikor a szervezetben a probléma megoldásában részt vevő munkatársak általában a korábbi tanulmányaik, illetve munkatapasztalatuk alapján kérnek fel szakértői munkára egy szakembert. Ezek a szakemberek egyetemeken oktatnak és/vagy markáns gyakorlati szakmai tapasztalattal rendelkeznek egy meghatározott területen, s nem feltétlenül van szakmai szövetség/társaság által minősített szakértői címük, illetve közel sem biztos, hogy igazságügyi szakértők. A közigazgatásban dolgozók számára viszonylag gyakran hirdetnek meg olyan állást, ahol rendszerint felsőfokú és/vagy szakirányú végzettséget írnak elő az ügyvivő szakértő munkakör betöltéséhez. Ezek az alkalmazottak változatos területeken (kommunikáció, igazgatás, könyvelés, müszaki ellenőr, tudás- és projektmenedzsment stb.) tevékenykednek.

A (4) végzettség alapján használt szakértői cím megszerzésénél négy nagy kategóriát lehet megkülönböztetni. (a) Korábban elterjedt gyakorlat volt, de még manapság is találkozhatunk vele, hogy azok, akik az alapdiplomájuk tudományterületéhez kapcsolódó területen végeztek szakirányú tanulmányokat, szakmérnökök/szakközgazdászok, míg akik egy másik területen, azok szakértők lettek az oklevelük alapján (képzési idő rendszerint 4 félév). Ebben a megközelítésben a szakmérnök alaposabb ismereteket szerzett, hiszen az alapdiplomája tudományterületén tanultakat bővítette, mélyítette, míg a szakértő az eredeti végzettségéhez nem illeszkedő területen szerzett ismereteivel szélesebb szakmai látókörre tett szert. Bár nem hangsúlyosan, de egy hierarchia is kialakult: a szakértők a rangsorban a szakmérnökök alatt helyezkedtek el. Egyes képző intézmények (pl.: Óbudai Egyetem - számítógép-hálózati, minőségbiztosítás, munkavédelem szak(irányú továbbképzés)) a végzettségben a szakmérnök, illetve a szakember megkülönböztetést teszik a fentebb leírtak szerinti felosztás alapján. (b) A diploma megnevezésében a szakértő szerepel, a képzési idő rendszerint 2-4 félév. A felvi.hu jelenleg a szakirányú továbbképzések között a BCE aktuárius szakértő, a BME közlekedési müszaki szakértő, a DUE, az EKE, a PPKE, illetve az SZE pedagógus szakvizsgához kapcsolódó, s meghatározott, nevesített területen szakértői feladatok ellátására felkészítő, illetve az SZE balesetvizsgálati szakterületen szakértői feladatokra felkészítő képzéseit nevezi meg. Az egyetemek (tovább)képzési kínálatát bemutató weboldalain lényegesen több szakértői képzést találunk, többek között környezetirányítási, terület- és településfejlesztési, nemzetközi kapcsolatok, kriminalisztika stb. területeken. (c) A 2017. június 20-tól érvényes Országos Képzési Jegyzék (OKJ) négy olyan felsőfokú végzettséghez kötött szakképesítést nevesít (okleveles adóellenőrzési, okleveles forgalmi adó, okleveles jövedelemadó, okleveles nemzetközi adó), amelyeknél az oklevél alapján a végzettek szakértők lesznek. A felsőfokú végzettség mellett a bemeneti követelmények között szerepel az adótanácsadói szakképesítés, valamint öt év adótanácsadói vagy adóigazgatási, vagy felsőfokú adóoktatási területen szerzett igazolt gyakorlat. Az iskolarendszeren kívüli képzési időt 160-300 óra között határozták meg, ami a gyakorlatban rendszerint 4-6 hónap időtartamban realizálódik. A közbeszerzés területén a végzettek rendszerint referensi bizonyítványt/tanúsítványt kapnak, de van olyan képző intézmény (pl.: Euzert Kft.), amelyik 5 nap alatt közbeszerzési szakértőket képez, illetve 2 nap alatt pályázati szakértőt. Ez utóbbi képzés jelenti az alapját a minősített pályázati projektmenedzser-képzésnek (5 nap). Az Országos Írásszakértő Intézet egy év alatt írásszakértőket képez. A tájékoztató szerint „Országos Írásszakértő Intézet Kft. írásszakértői magánoklevelét kapják a hallgatóink, mellyel eseti szakértőként (2005. évi XLVII. törvény 1.§ 3. bekezdése) föleg bíróságok, ügyészségek, rendőrségek munkáját segíthetik”. (d) Több szakmai szövetség indít olyan rövidebb-hosszabb képzést, amelyiknél a végzettség megnevezésében a szakértő szerepel. A Grafológusok és Írásszakértők Országos Szövetsége a fentebb nevezett intézethez hasonlóan egy éves képzést indít, „melynek elvégzése után, valamint a vizsgakövetelményeknek eleget téve, az írásszakértői munkavégzéshez szükséges tanúsítvány kapnak a résztvevők". Ennél lényegesen rövidebb idő (3-5 nap, illetve néhány hét) alatt is lehet az OKJ-ban nem szereplő szakmában olyan tanúsítványt kapni, amelyikben a szakértő megnevezésre kerül. A Bankszövetség és a Bankárképző közös képzésén például 3 nap alatt lehet szerezni képesített compliance szakértő tanúsítványt. A tanulmányi és vizsgaszabályzat szerint „A programra bárki jelentkezhet, aki legalább érettségivel rendelkezik", illetve a programon való részvételhez felvételi vizsgát tesz. A képző intézmény további öt olyan képzés kínál, amelyeknél a szakértő szó szerepel, s hasonló a képzési idő, illetve a bemeneti követelmény. A Magyar Public Relations Szövetség ugyancsak rövid idő alatt (22 óra) kínál szakértő képzést rendezvényi protokoll területen.

A (5) szakmai szövetségek, szervezetek, kamarák szakértői minösitő rendszere hasonló elvek szerint müködik. A szakirányú (felsőfokú) végzettség, a szakmérnök, szakértő, szakember megnevezésű végzettséget tanúsító továbbképzés, az igazolható szakmai gyakorlat (rendszerint 3-5 év), két szakértő ajánlása, a szövetség érdekében végzett aktív tevékenység (pl.: előadás tartása, tanácsadás a szövetség tagjainak, tisztség), (felső)oktatási tapasztalat, kutatási és publikációs tapasztalat, s a felsoroltak összessége, vagy egy része szerepel eltérő súllyal a minősítési szempontok között. A szakértői cím vagy egy életre szól, vagy egy bizonyos időszakra, ez utóbbinál a cím meg- 
tartásának feltétele az előírt továbbképzés, gyakorlat stb. megszerzése. A kapcsolódó tudományterületen/témában szerzett doktori fokozatot $(\mathrm{PhD})$ több szakmai szervezet honoris causa alapon automatikusan szakértői minősítéssel ismer el, a jelentkezőnek csak a szükséges jelentkezési lapot kell kitöltenie. A szakmai szövetségek, szervezetek, kamarák többsége szakértői névsorát nyilvánossá teszi a szakértői terület megnevezésével együtt.

Vannak olyan (6) szakmai/nonprofit szervezetek, amelyek szakmai szolgáltatásokat nyújtanak tagságuknak, illetve megbízóiknak. Ezek a szervezetek (pl.: Független Pedagógiai Intézet) is elkészítik szakértői listájukat a szakértő nevének és szakterületének a feltüntetésével. Azért tartom fontosnak az (5) és a (6) megkülönböztetését, mert az előbbinél rendszerint egy sokkal átláthatóbb, számos követelmény teljesítését feltételező minősítő rendszer alapján lesz a jelöltből szakértő, míg az utóbbinál nem minden esetben lehet megállapítani, hogy mi alapján kerülnek fel a (szak)emberek a szakértői listára.

2017 január elsején kezdte el müködését a (7) Nemzeti Szakértői és Kutató Központ (NSZKK), amelyik az Igazságügyi Szakértői és Kutató Intézetek és a Bünügyi Szakértői és Kutatóintézet összeolvadásával alakult meg. Az NSZKK 12 központi intézetet/osztályt, illetve 11 területi intézetet foglal magába. Az NSZKK köszöntőjében megfogalmazza, hogy ,az összeolvadással elérni kívánt cél egy Magyarországon egyedülálló, egységes szakértői intézmény életre hívása volt, amely független, pártatlan, részrehajlásmentes, a hivatalos eljárásokban meghivatkozható, helytálló és magas szakmai színvonalú szakértői véleményt nyújt az állam szerveinek éppúgy, mint polgárainak". A Nemzetbiztonsági Szakszolgálat (NBSZ) fennhatósága alatt is müködnek szakértői intézetek, melyek okmányszakértői, vegyész-szakértői, írásszakértői, nyelvész-szakértői, hangszakértő, fotó-videó szakértői, informatikai szakértői területeken tevékenykednek, s említést érdemel a NAV Szakértői Intézete is.

Törvények és rendeletek alapján számos szakértői névjegyzékkel lehet találkozni. Szociális területen a szocialisportal.hu megfogalmazása szerint „A Kormány által erre kijelölt szerv a szakértői tevékenység folytatására engedéllyel rendelkező személyekről a szociális igazgatásról és szociális ellátásokról szóló 1993. évi III. törvény, illetve a gyermekek védelméről és a gyámügyi igazgatásról szóló 1997. évi XXXI. törvény szerint névjegyzéket vezet”. A 8/2012. (II. 21.) NEFMI rendelet a foglalkozási rehabilitációs szakértők névjegyzékéről, a 25/2009. (XI. 13.) SZMM rendelet az Országos Gyermekvédelmi Szakértői Névjegyzékről és az Országos Szociálpolitikai Szakértői Névjegyzékről, 47/2012. (XII. 11.) EMMI rendelet a rehabilitációs orvosszakértői névjegyzékről rendelkezik. A nevezett rendeletek részletesen szabályozzák a szakértői névjegyzékbe kerülés feltételeit, illetve rendszerint meghatározzák a továbbképzés követelményeit is. A köznevelési szakértői tevékenység folytatására jogosult szakértők országos szakértői névjegyzékének jogi alapját a nemzeti köznevelésről szóló 2011. évi CXC. törvény adja meg. A szakértői tevékenység folytatásának feltételeit a köznevelési szakértői tevékenységről, valamint az érettségi vizs- gaelnöki megbízás feltételeiről szóló 15/2015. (III. 13.) EMMI rendelet határozza meg. Az adótanácsadói, az adószakértői és az okleveles adószakértői tevékenység végzésére jogosító engedélyek kiadásának és visszavonásának feltételeiről, továbbá a kapcsolódó nyilvántartás vezetésének és a nyilvántartásban szereplők továbbképzésének szabályairól szóló 26/2008. (VIII. 30.) PM rendelet említést tesz az igazságügyi szakértői névjegyzékről (részletesen később). A Magyar Könyvvizsgálói Kamaráról, a könyvvizsgálói tevékenységről, valamint a könyvvizsgálói közfelügyeletről szóló 2007. évi LXXV. törvény értelmében a Kamara szakértői véleményt alakít ki az adózás rendjéröl szóló törvény 132. § (5b) bekezdése alapján az IFRS-ek szerinti számviteli elszámolás minősítését is igénylő feltételes adómegállapítás iránti kérelem esetén, a számviteli elszámolás minősítésére vonatkozóan. A törvény könyvvizsgálói igazolványra vonatkozó részében leírja, hogy a kamarai tag könyvvizsgáló jogosult a „könyvszakértő” cím használatára. A Kamara szervezetéről szóló rész nevesíti a szakértői bizottságot. A tervező- és szakértő mérnökök, valamint építészek szakmai kamaráiról szóló 1996. évi LVIII. törvény részletesen leírja, hogy mely adatoknak kell szerepelnie a névjegyzékben.

A törvények és rendeletek között kiemelt helyet foglal el az (8) igazságügyi szakértőkröl szóló 2016. évi XXIX. törvény, az igazságügyi szakértői névjegyzék vezetéséről szóló 210/2005. (X. 5.) Korm. rendelet, az igazságügyi szakértői müködésről szóló 31/2008. (XII. 31.) IRM rendelet, az igazságügyi szakértői tevékenység folytatásához szükséges jogi oktatásról és vizsgáról szóló 10/2006. (III. 7.) IM rendelet, valamint az igazságügyi szakértői szakterületekről, valamint az azokhoz kapcsolódó képesítési és egyéb szakmai feltételekről szóló 9/2006. (II. 27.) IM rendelet. Az igazságügyi szakértői igazolványról 19/2006. (IV. 24.) IM rendelet leírja, hogy a Büntető Törvénykönyvről szóló 2012. évi C. törvény 459. § (1) bekezdés 12. Pontjának e) alpontja alapján az igazságügyi szakértő a bírósági vagy más hatósági eljárásban közfeladatot ellátó személynek minősül. A 2016. évi XXIX. törvény értelmében igazságügyi szakértői tevékenységet

„a) természetes személy (a továbbiakban: igazságügyi szakértő),

b) gazdasági társaság (a továbbiakban: társaság) és szolgáltató,

c) igazságügyi szakértői intézmény és igazságügyi szakértői intézet,

d) igazságügyi szakértői testület,

e) külön jogszabályban feljogosított állami szerv, intézmény, intézet és szervezet (a továbbiakban együtt: szervezet) és

f) külön törvény szerinti Teljesítésigazolási Szakértői Szerv végezhet".

A törvény biztosítja, hogy a megfelelő szakértelemmel rendelkező eseti szakértő igénybevételét azokban az esetekben, amikor az adott szakterületen nincs bejegyzett igazságügyi szakértő, vagy van, de a felkérésnek/kirendelésnek nem tud eleget tenni, vagy a rendeletben nevesített szakterületek között az adott szakterület nem szerepel. Az 
igazságügyi szakértővé válás fontos része a névjegyzékbe történő felvétel (az igazságügyi szakértői névjegyzék tartalmát a Törvény I. melléklete tartalmazza). Ennek fontosabb feltételei: a jelentkező büntetlen elöéletü, nem áll foglalkozástól/közügyektől eltiltás hatálya alatt, az általa megjelölt szakterülethez illeszkedő képesítéssel rendelkezik, minimum öt év szakirányú szakmai gyakorlata van, a szakértőjelölti feltételeket teljesítette, részt vett az igazságügyi szakértők számára szervezett jogi ismeretek oktatásán és sikeres vizsgát tett, tagja az illetékes szakmai kamarának, vállalja, hogy a hatósági kirendelésnek eleget tesz, önállóan döntésképes. A névjegyzékböl történő törléssel gyakorlatilag megszünik a szakember igazságügyi szakértői jogosultsága. Bár alapvetően a szakértő fogalmazza meg véleményét írásban vagy szóban, ennek kialakításában szakkonzultáns, illetve segédszemélyzet segítségét is igénybe veheti.

Az 1. táblázat a fent leírtak alapján saját szempontjaim szerint mutatja be az egyes szakértői csoportba tartozók fontosabb tulajdonságait.
Összességében megállapítható, hogy az elemzés során bevont dokumentumok és (online) tartalmak alapján meglehetősen heterogén képet mutat a szakmai szolgáltatások közül a szakértő. Látható, hogy egyaránt találkozhatunk önjelölt, igazolható, komoly végzettséggel nem rendelkező laikusokkal, illetve komolyabb minősítésen átesett, igazolható szakmai gyakorlattal és releváns, elismert végzettséggel rendelkező, aktív szakmai (esetleg tudományos) életet folytató, szakértői jogosultságát időről-időre továbbképzéssel megújító szakemberekkel is. A laikusok és a szakértők közötti markáns különbség mutatkozik többek között a kockázatértékelés területén. A szakértők a várható potenciális veszélyre, és annak bekövetkezési valószínüségének a minimalizálására törekednek, s a laikusokkal ellentétben több információ alapján alkotnak ítéletet, bár ők sem mentesek a torzításoktól (Kádi, 2016). Z. Karvalics (2015) szerint, ,gyakran tapasztaljuk, hogy a „laikus” és a „szakértő” pozíciója egészen közel tud kerülni egymáshoz: a mindössze néhány müveletből építkező kívülálló is könnyüszerrel juthat el helyes következteté-

1. táblázat

Az egyes szakértői csoportok fontosabb ismérvei (saját szerkesztés)

\begin{tabular}{|c|c|c|c|c|c|c|c|c|}
\hline $\begin{array}{c}\text { Csoport száma } \\
\text { / ismérv }\end{array}$ & 1 & 2 & 3 & 4 & 5 & 6 & 7 & 8 \\
\hline $\begin{array}{c}\text { szakértővé } \\
\text { válás } \\
\text { időtartama }\end{array}$ & $\begin{array}{c}\text { közel } \\
\text { azonnal }\end{array}$ & $\begin{array}{c}\text { közel } \\
\text { azonnal }\end{array}$ & $\begin{array}{l}\text { kinevezés, } \\
\text { vagy } \\
\text { pályázat át- } \\
\text { futási ideje }\end{array}$ & $\begin{array}{c}2 \text { nap }-2 \text { év } \\
\text { között }\end{array}$ & $\begin{array}{l}\text { pályázat át- } \\
\text { futási ideje }\end{array}$ & $\begin{array}{l}\text { kinevezés, } \\
\text { vagy } \\
\text { pályázat át- } \\
\text { futási ideje }\end{array}$ & $\begin{array}{c}\text { kinevezés, vagy } \\
\text { pályázat átfutá- } \\
\text { si ideje }\end{array}$ & $\begin{array}{c}\text { pályázat átfutási } \\
\text { ideje }\end{array}$ \\
\hline $\begin{array}{c}\text { ki minősíti } \\
\text { szakértőnek }\end{array}$ & $\begin{array}{l}\text { saját } \\
\text { maga }\end{array}$ & $\begin{array}{l}\text { média és } \\
\text { saját maga }\end{array}$ & megbízó & $\begin{array}{l}\text { oktatási } \\
\text { intézmény, } \\
\text { OKJ }\end{array}$ & $\begin{array}{l}\text { szakmai } \\
\text { szövetség, } \\
\text { kamara }\end{array}$ & $\begin{array}{l}\text { nonprofit } \\
\text { szervezet }\end{array}$ & $\begin{array}{l}\text { állami } \\
\text { szervezet, } \\
\text { rendszerint } \\
\text { minősítö } \\
\text { bizottság } \\
\end{array}$ & \begin{tabular}{|c|} 
rendszerint \\
mi-nősítő bizott- \\
ság jogszabályi \\
megfelelés alap- \\
ján \\
\end{tabular} \\
\hline végzettség & \multirow{3}{*}{$\begin{array}{l}\text { nem } \\
\text { szük- } \\
\text { séges, } \\
\text { "legyárt- } \\
\text { ható" }\end{array}$} & \multirow{3}{*}{$\begin{array}{l}\text { szerkesztő } \\
\text { ellenőrzi, } \\
\text { digitális } \\
\text { lábnyom } \\
\text { alapján }\end{array}$} & \multirow{3}{*}{$\begin{array}{c}\text { törvényi } \\
\text { elöírás, vagy } \\
\text { elvárt }\end{array}$} & kötelező & kötelező & \multirow{3}{*}{$\begin{array}{l}\text { rendszerint } \\
\text { szükséges, } \\
\text { pályázati ki- } \\
\text { írástól függ }\end{array}$} & kötelező & kötelező \\
\hline tapasztalat & & & & $\begin{array}{l}\text { nem feltét- } \\
\text { lenül szük- }\end{array}$ & $\begin{array}{c}\text { rendszerint } \\
3-5 \text { év }\end{array}$ & & kötelező & kötelező \\
\hline $\begin{array}{c}\text { igazolható } \\
\text { szakmai múlt }\end{array}$ & & & & $\begin{array}{c}\text { séges } \\
\text { (pályakezdő) }\end{array}$ & kötelező & & kötelezö & $\begin{array}{c}\text { kötelező, min. } \\
5 \text { év }\end{array}$ \\
\hline $\begin{array}{c}\text { szakértői név- } \\
\text { jegyzék } \\
\text { (publikus) }\end{array}$ & - & $\begin{array}{l}\text { szerkesz- } \\
\text { tő saját } \\
\text { címlistája } \\
\text { (nem) }\end{array}$ & nem jellemzö & $\begin{array}{l}\text { lehet (rend- } \\
\text { szerint nem) }\end{array}$ & $\begin{array}{l}\text { szinte min- } \\
\text { dig van } \\
\text { (rendszerint } \\
\text { igen) }\end{array}$ & $\begin{array}{l}\text { szinte min- } \\
\text { dig van } \\
\text { (rendszerint } \\
\text { igen) }\end{array}$ & $\begin{array}{l}\text { szinte mindig } \\
\text { van (igen, ki- } \\
\text { véve speciális } \\
\text { eseteket) }\end{array}$ & $\begin{array}{c}\text { van, a szakér- } \\
\text { tővé válás felté- } \\
\text { tele a bekerülés } \\
\text { (igen) }\end{array}$ \\
\hline $\begin{array}{l}\text { szakértő cím } \\
\text { megszünése }\end{array}$ & $\begin{array}{c}\text { saját } \\
\text { döntés } \\
\text { alapján }\end{array}$ & $\begin{array}{l}\text { nem kérik } \\
\text { többet fel } \\
\text { médiasze- } \\
\text { replésre }\end{array}$ & $\begin{array}{c}\text { szerződés } \\
\text { megszünik, } \\
\text { a szakértő a } \\
\text { munkát elvé- } \\
\text { gezte }\end{array}$ & $\begin{array}{l}\text { nem vesz } \\
\text { részt tovább- } \\
\text { képzésen (ha } \\
\text { a jogszabály } \\
\text { kötelezővé } \\
\text { teszi) }\end{array}$ & $\begin{array}{l}\text { etikai vétség, } \\
\text { nem újítja } \\
\text { meg a címet } \\
\text { a szövetség } \\
\text { belső szabá- } \\
\text { lyai szerint }\end{array}$ & $\begin{array}{l}\text { etikai vétség, } \\
\text { kilép a } \\
\text { nonprofit } \\
\text { szervezetből. } \\
\text { foglalkozta- } \\
\text { tás megszü- } \\
\text { nik }\end{array}$ & $\begin{array}{l}\text { foglalkoztatása } \\
\text { megszünik, } \\
\text { kilép az állami } \\
\text { szervezetböl, } \\
\text { törlik a név- } \\
\text { jegyzékből }\end{array}$ & $\begin{array}{c}\text { törlik a névjegy- } \\
\text { zékböl }\end{array}$ \\
\hline $\begin{array}{c}\text { jogszabályi } \\
\text { keret }\end{array}$ & - & - & $\begin{array}{l}\text { lehet, pl.: } \\
\text { közalkalma- } \\
\text { zotti törvény }\end{array}$ & $\begin{array}{l}\text { lehet, pl.: } \\
\text { szakképzési } \\
\text { törvény, } \\
\text { felsőoktatási } \\
\text { törvény }\end{array}$ & $\begin{array}{l}\text { lehet, több } \\
\text { törvény, szá- } \\
\text { mos rendelet }\end{array}$ & $\begin{array}{l}\text { lehet, pl.: az } \\
\text { adott tevé- } \\
\text { kenységhez } \\
\text { kapcsolódó }\end{array}$ & mindig van & mindig van \\
\hline
\end{tabular}


sekig, ha megfelelően kombinál igazolt ismeretdarabokat, és azokat hatékonyan értelmezi”. Ilyen megközelítésből a problémák komplex kezelése és az összetett problémák eredményes megoldása inkább a valódi szakértőket jellemzi (5., 7., 8. csoportok).

Tévedés lenne azt állítani, hogy a szakértők minden esetben a veteránok, a baby boom, az X-, illetve az Y- generáció idősebb tagjai közül kerülnek ki. Bár a többéves szakmai tapasztalat és a többéves tanulás révén megszerzett iskolai végzettség együttese teszi általában hitelesebbé a megbízó szemében a szakértőt, az informatika, illetve az információ- és informatikai biztonság területén a fiatal (fiatalabb Y-generációsok, illetve Z- generációsok) személyek tudásuk és tapasztalatuk révén képesek lehetnek szakértői feladatok ellátására.

A kutató számára az lenne az ideális, ha elsősorban az 5., 7., 8. csoportokból tudná kiválasztani azokat, akiket megkérdez, akikkel interjút készít, vagy fókuszcsoportos beszélgetést folytat. A tanulmányomban bemutatott eseteknél csak részint hagyatkoztam ezeknek a minősített szakértőknek a véleményére, mivel csekély számban álltak rendelkezésemre. Így más megoldást választottam. Öket neveztem el a (9) kutató által minösitett szakembernek (vagy más névvel minősített szakértőnek - elnevezésében rokonítva a 2., illetve 3. csoport tagjaihoz), kiválasztásukról a következő fejezetben értekezem.

\section{A szakértői kiválasztás folyamata}

Mielőtt a szakértői kiválasztás folyamatát bemutatom, szeretném megadni a fogalom többsíkú értelmezését Bogner és Littig (2014) felvetése alapján. A fogalom voluntarista (Wundt, 1898; Tönnes, 2004) interpretációjában azt mondhatjuk, hogy mindenki a saját élete szakértője. Ez azt jelenti, hogy ha a kutató életinterjúkat vesz fel emberekkel, akkor azok (szubjektív) véleménye szakértői véleményként is értelmezhető a saját életkeretükben. Ilyen megközelítésből a kutatásomban bemutatott 1-es csoport (önjelölt szakértő) is ide sorolható, hiszen ők erős akarattal szakértők akarnak lenni és annak is mondják magukat. A müszaki-gazdasági-orvosi-szakmai életben ez a megközelítés sántít, így sokkal inkább a konstruktivista (Hess, 1997) megközelítés alapján jutunk el a fogalomhoz: a szakértők különleges tudással rendelkeznek, a kutatók szakértői szerepet tulajdonítanak a szakembereknek, illetve a társadalom a speciális tudás és a speciális funkciók alapján minősítik a szakembereket szakértőnek. Ezzel a megközelítéssel lehet találkozni akkor, amikor a média vagy a megbízó minősíti a szakértőt. Tudományszociológiai értelemben (Bogner - Littig, 2014) a szakértők speciális tudással rendelkeznek, ami saját szakmájukhoz kapcsolódik, a magabiztos tudásra összpontosítanak, gyakran nem lehet besorolni őket egy szakmába, mivel ismeretanyaguk a szakma általános ismereti keretén túlmutat és/vagy sokkal mélyebb, ismereteiket folyamatosan megújítják, frissítik. Ilyenformán ebbe a csoportba tartoznak a különböző minősítő szervezetek által minősített szakértők, illetve az igazságügyi szakértők is.
Saját kutatási eredményeim, illetve Bogner és Littig (2014) megállapításai alapján a tudományos igényű kutatásba bevont szakértőket az alábbi tulajdonságok jellemzik:

- magas fokú szakmai ismeret,

- a gazdasági-múszaki stb. folyamatokhoz kapcsolódó ismeretek,

- az adott ágazat/iparág/terület fejlődési irányainak az ismerete,

- ismereteit folyamatosan bővíti,

- értelmező, értékelő, elemző ismeretekkel rendelkezik, illetve ezeket a módszerek használja,

- a rendelkezésére álló vállalati és egyéb források alapján határozott és megalapozott véleményt képes kialakítani,

- véleményét érthető módon rendszerint írásban, ritkábban csak szóban fogalmazza meg,

- a megállapításait a gyakorlatba átültetve a probléma mérsékelhető, megoldható.

Előnynek számít továbbá a szakmai-tudományos közéleti aktivitás (pl.: konferencia-előadás, részvétel a felsőoktatásban, publikációs tevékenység), a szakmai-tudományos szervezetek minősítése (pl.: a szakmai szervezet szakértője, szerepel a szervezet szakértői névlistáján), a jogi elöírásoknak való megfelelés (pl.: szükséges képzés sikeres elvégzése, továbbképzéseken való részvétel, büntetlen elöélet). Fent nevezett tulajdonságok összevethetöek Tokár-Szadai (2017) a vezetési tanácsadók kiválasztási szempontjairól írt gondolataival: a megfelelő szakmai/ tárgyi tudás, az ügyfél elismerése (felnéz rá) és bizalma alapérték mindkét szakmai szolgáltató hivatás esetében.

A szakértői csoport létrehozásakor Ivlev és munkatársai (2015) szerint az alábbi feladatokat kell megoldani:

1. megérteni azt a feladatot/problémát, amit majd a szakértők megoldanak,

2. meghatározni a feladathoz/problémához kapcsolódó tevékenységi területeket,

3. eldönteni, hogy a csapatban milyen arányban osztoznak az egyes területeket képviselö szakértők,

4. meghatározni a csapat szakértőinek a létszámát és összeállítani a szakértői listát,

5. elemezni a szakértők minősítését,

6. felkérni a szakértőket a munkára, megállapodni velük,

7. a szakértők listájának véglegesítése.

(1) A feladat/probléma megértése. Amikor a megbízó vagy a kutató azon gondolkozik, hogy van-e értelme külsős szakembert meghívni és/vagy a belsős kollégákból egy szakértői csoportot képezni, a legnehezebb feladat az, hogy a problémát megértse. A megbízó és a belsős kollégák bevonódása/érintettsége miatt gyakran a problémát nem súlyához mérten értékelik, ami azt jelenti, hogy felértékelése esetén lényegesen több szakértőt, $\mathrm{s}$ ezáltal több erőforrást vonnak be a megoldási folyamatba, alulértékelés esetén pedig úgy is dönthetnek, hogy egy egyszerü csoportos megbeszéléssel és az ott alkalmazott kreatív 
módszerrel (pl.: brainstorming) a munkatársak is képesek megoldani a problémát. A (súlyosabb, nagyobb horderejü) probléma megfogalmazásakor érdemes lehet olyan coach-szakértőt felkérni, aki megannyi kérdést tesz fel annak érdekében, hogy a problémát, illetve a célt világosan lehessen látni (Vogelauer, 2002; Wehrle, 2014). A kutatók is élhetnek ezzel a lehetőséggel, a szakma által megbecsült, s megfelelő minősítéssel rendelkező szakértővel folytathatnak eszmecserét.

(2) A feladathoz/problémához kapcsolódó tevékenységi területek meghatározása. Ezt a tevékenységet a kutató vagy önállóan, vagy ritkábban a korábban már említett coach-szakértő bevonásával végezheti. Kapcsolódó tevékenység rendszerint a kutatás megszervezése (pl.: helyszín, kutatási módszer(ek), szakértők száma, segédeszközök, szakértők elsőkörös kiválasztása, meghívók kiküldése, szakértői visszajelzések kezelése, témák meghatározása), az eredmények feldolgozása és értékelése, a kutatási jelentés(ek) és prezentáció(k) elkészítése, az eredmények nyilvános (pl.: szakmai konferencia), vagy zárt (pl.: munkaértekezlet) bemutatása. A kapcsolódó témák meghatározásánál a kutató használhatja az elmetérkép (Arthur, 2012) módszerét, aminek eredményeként a problémához illeszkedő fontosabb témák/fogalmak kapcsolatrendszere rajzolható meg. A módszer egyszerü, akár papíron, akár szabadon használható szoftverrel is megrajzolható az elmetérkép. Hatékonysága elsősorban attól függ, hogy ha a kutatót coach-szakértő segíti, akkor menynyire képes a vizsgálandó problémát és annak kapcsolódásait feltérképezni, ha pedig nem, akkor a kutató mennyi időt fordít a probléma és az összefüggések megismerésére (szekunder kutatás).

(3) Eldönteni, hogy a csapatban milyen arányban vesznek részt az egyes területeket képviselö szakértők. Ha a kutató az előző pontban említett elmetérkép módszerével megrajzolta a probléma kapcsolódó témáinak/területeinek fogalmi térképét, akkor láthatóvá válik, hogy melyek azok a témák/területek, amelyek hangsúlyosabban kell, hogy szerepeljenek a vizsgálatban. A lehetséges szakértők előzetes téma-, illetve területkompetenciái alapján (forrás: önéletrajz, hiteles személyes márka) meghatározhatók a témaarányok, s ennek alapján az egyes témákat képviselő szakértők száma. Megjegyzem, hogy a kutató - ahogy arra már utaltam korábban - nem csak szakértői titulust használó szakembereket kérhet fel szakértői munkára, hiszen többek között a szaktanácsadó, a szakmérnök, szakorvos, szakközgazdász stb., a tanácsadó, a referens, a munkatárs, az auditor, a konzultáns, a szakkonzultáns egyaránt alkalmas lehet a feladat igényes és megfelelö szintü elvégzésére.

(4) Meghatározni a csapat szakértőinek a létszámát és összeállitani a szakértői listát. Ideális esetben a szakértői csapatban megtalálhatók a csak egy szakterületre szakosodott, illetve több területen is jártas szakértők. Így biztosítható a téma diverzitása, aminek alapján a probléma több szempontból, az egyes szempontok ütköztetése révén mélyrehatóbban, komplexebb módon vizsgálható. A szakértők létszámának meghatározása a kutatási módszertől függ (részletesen lásd később), a lista összeállítá- sánál figyelembe kell venni, hogy ez még szükülni fog több ok miatt is (pl.: a szakértő visszautasítja a felkérést, nem szeretne együtt dolgozni más szakértőkkel, a szakértő részletes minősítése során több szakértő mégsem felel meg az elvárásoknak - következő pont). A szakértői lista összeállításában segíthet, ha a kutató az általa ismert néhány szakértőt megkéri, hogy a probléma és a kapcsolódó témák ismeretében tegyen ajánlást a szakértői csoport öszszetételére. Ez módszertanilag a hólabdás mintavételhez (Malhotra, 2002) hasonlít.

(5) Elemezni a szakértők minősitését. Nováky (1999) a szakértői kompetenciák meghatározásában a Grigorov-, illetve a Helmer-féle mutatókat javasolja. (a) Grigorov objektív és szubjektív mutatók használatával határozza meg a szakértő kompetenciáját. Objektív mutatóknál a szakértő egy előre elkészített kérdőívet tölt ki, amelyik a szakértő minősítését és így kompetenciáinak meghatározását teszi lehetővé. A kérdőív kitér többek között a végzettségre, a tudományos-szakmai minősítésre, a gyakorlati tapasztalatra, az életkorra, az adott területen eltöltött időre. Ezeket a válaszokat a kutatásvezető számszerüsíti (gyakran csak próbálja számszerüsíteni) öt-, illetve tízfokú skálán. A szubjektív vizsgálat során a problémához illeszkedő területeken és témákban (lásd: elmetérkép - (2) pont) a szakértő maga értékeli, hogy mennyire járatos az adott kérdéskörben (pl.: öt-, illetve tízfokú skálán). Az objektív és a szubjektív mutatók átlaga alapján szorzatokat képeznek (1-25, illetve 1-100 közötti értéket kapnak), s e szorzatok jelzik, hogy a szakértő mennyire ért az adott témához/kérdéshez. Megjegyzem, hogy ez a módszer csak akkor valósítható meg, ha a szakértői megkérdezés során választott módszernél mindvégig nyomon követhető, s az adott szakértőhöz rendelhető valamennyi válasza. (b) Helmer a szakértő korábbi elörejelzéseinek a bekövetkezése alapján minősít, $\mathrm{s}$ abszolút és relatív megbízhatósági fokkal méri a hozzáértésüket. Az abszolút megbízhatósági fok meghatározása: a szakértő bekövetkezett előrejelzéseinek a számát osztja az összes elörejelzésének a számával (ideális esetben ennek értéke maximum 1 lehet). A relatív megbízhatóság a szakértő abszolút megbízhatósága és a csoportátlag megbízhatósága hányadosából képződik. Ha értéke nagyobb, mint egy, a szakértő átlag feletti tudással/tapasztalattal rendelkezik a témában. Megítélésem szerint a gyakorlati életben - különösen nagyobb létszámú szakértői csoporttal történő kutatás során - a helmeri módszertan azért nem célravezető, mert a kutatónak sok időt kell fordítania a szakértők valamennyi előrejelzésének a megismerésére és a bekövetkezés ellenörzésére. Ha a szakértők ismerik egymást, akkor (c) a szociometria (pl.: Mérei, 2006) önálló, illetve a grigorovi szubjektív mutató együttes alkalmazása is célravezető lehet. Az elmetérkép segítségével megnevezett fogalmakra építve olyan kérdések tehetők fel a szakértőknek, hogy (létszámuktól függően) ki az a 3-5 szakember, aki szerintük a legjobban ért az adott témához. Ennek alapján az adott témánál megnevezett szakértők említési gyakorisága alapján rangsor állítható fel, majd e rangsor alapján pontozni lehet a szakértő kompetenciáját (pl.: ahány említés, annyi pont). A szakértő emellett egy másik kérdőívet is kaphat, 
amelyiknél valamennyi témában értékelheti a szakértelmét egy öt-, illetve tízfokú skálán. A két eredmény alapján szorzat képezhető, s valamennyi témánál meghatározható a szakértők kompetencia-sorrendje. (d) Valamely feladat elözetes elvégeztetése és kutatói értékelése. Ha a kutató ért a témához, akkor a szakértőknek adhat előzetesen egy-két feladatot, aminek elvégeztetése után értékeli az eredményeket (pl. ötfokú skálán vagy százalékban). Így a szakértőkről egy általános véleményt alakíthat ki, illetve rangsort állíthat fel. Ha fontosnak tartja, a grigorovi szubjektív mutatót is képezve az osztályzat/százalékos érték és e mutató szorzata alapján megalkothatja a szakértők végső rangsorát.

(6) Felkérni a szakértőket a munkára, megállapodni velük. Ahogy az előző pontokban már láthattuk, bár a szakértők felkérése és a megállapodás ebben a pontban történik, az előzetes kiválasztás, az objektív/szubjektív, s egyéb értékelések és kompetenciák felmérése során a kutató már felvette/felvehette a kapcsolatot a szakértőkkel. A hivatalos felkérésnél a (2)-es pontban meghatározott, s a többi pontban körülhatárolt és definiált problémát és a kapcsolódó témákat fogalmazzák meg. A kutató a felkérőlevélben kitér a kutatás módszertanára (lásd később), ha a módszertan megkívánja, hogy a szakértők adott helyen és időben (pl.: fókuszcsoportos megkérdezés) legyenek együtt, akkor megnevezheti a csoport többi tagját, jobb esetben elkerülve azt, hogy az esetleg egymással nem szimpatizáló szakértők személyeskedjenek, ahelyett, hogy a probléma megoldására fókuszálnának. A felkérőlevél része a szakértői díj összegének és a kifizetés módjának és határidejének a feltüntetése is, ha a kutatónak van pénzügyi kerete erre.

(7) A szakértők listájának véglegesitése. A szakértők visszajelzése alapján a kutató véglegesíteni tudja a szakértői listát, s a felkérölevélben leírtak szerint hozzá tud kezdeni a szakértői megkérdezés megvalósításához.

\section{A szakértői megkérdezés módszerei}

A szakértői megkérdezésről/mintavételről általánosságban azt mondhatjuk, hogy „,nem valószínűségi mintavételi eljárás" (Babbie, 2000, p. 243.), s Babbie a kvótás mintavétellel és a könnyen elérhető személyek megkérdezésével egy csoportba sorolja. Malhotra (2002) a nem véletlen mintavételi technikáknál az önkényes mintavételt ( könynyen elérhető személyek megkérdezése), az elbírálásos mintavételt ( $\sim$ szakértői minősítés alapján történő kiválasztás), a kvótás mintavételt ( szakértői kiválasztás (3)as pontja), illetve a hólabda-mintavételt különbözteti meg. A szakértői megkérdezés kapcsán elfogadható Malhotra (2000, p. 406-407.) azon állítása, hogy ,,a kutató önhatalmúlag, vagy valamilyen meggyőződése alapján döntheti el, mely elemek kerüljenek a mintába”, ugyanakkor az a véleménye, hogy ,a kapott becslések statisztikailag nem általánosíthatók a sokaságra" nem értelmezhetők a szakértői megkérdezésnél, hiszen maga a probléma körülhatárolásánál és a téma kapcsolatainál rendszerint nem az a kérdés, hogy az (alap)sokaság hogyan vélekedik erről, hanem az, hogy a szakértők között véleményazonosság, vagy -különbség van, s ha ez utóbbi, akkor milyen dimenziók és arányok mentén. Többféle módon lehet a szakértői véleményeket megszerezni, megismerni, feldolgozni, öszszevetni, értékelni. Megkülönböztethetünk többek között primer és szekunder módszereket, illetve a szakértők száma alapján, valamint a közöttük levő interakció révén is nevesíthetünk módszereket/eljárásokat. Az alábbiakban a számos módszer közül azokat veszem sorra, amelyek nem csak a szakirodalomban szerepelnek, hanem a korábban említett 27 szakértővel folytatott telefonos/személyes interjú során is megneveztem, illetve saját 2017-es kutatásunkban módszerként használtuk fel (szinektika). Megjegyzem, hogy a módszerek egy részénél a megkérdezett szakértők eltértek a szakirodalomban leírt módszertantól, s személyiségükhöz, illetve az együttműködő (szakértői) csoport közös igényeihez és céljához jobban illeszkedő módosításokkal használták a megnevezett eljárásokat. Véleményük ugyan nem tekinthető a statisztikai módszertan szerint reprezentatívnak, de megítélésem szerint jelzi, hogy a szakértőkben igény van a tanult módszerek továbbgondolására és a feladathoz/megbízáshoz jobban illeszkedő módszerváltozatok használatára. Megjegyzem továbbá, hogy a szakértői megkérdezés módszereinek egy része a szakértők kiválasztására is használható, mivel a végső, az összetett problémára megoldást kereső szakértői csoport megalkotása is a módszerfolyamat részét képezi.

(1) A szekunder módszer módszertanilag leginkább a szekunder források, illetve a dokumentumok gyüjtéséhez és (tartalmi) elemzéséhez hasonlít (Krippendorff, 1995) azzal a lényeges különbséggel, hogy a kutató csak a (a) hiteles szakmai múlttal rendelkező szakértő, a (b) szakértői intézet, vagy (c) egyéb szakértői igényességü dokumentumot kibocsátó szervezet dokumentumait tekinti megfelelő forrásnak. A kutató kutatási jelentésében - a szekunder források feldolgozásához hasonlóan - megnevezi a forrást. Ha a kutató csak egy szakértő véleményét közli komolyabb saját hozzáadott érték (pl.: vélemény, kritikai észrevétel) nélkül, akkor az gyakorlatilag nem tekinthető a kutató saját, igényes munkájának. Célravezetőbb több szekunder forrást feldolgozni úgy, hogy a kutató saját szempontrendszere alapján kategorizálja, értékeli, veti össze a forrásokat, majd kialakítja markáns véleményét. A szakértői forrásokon alapuló szekunder kutatás olcsó, viszonylag gyorsan lehet eredményeket közölni, bár - ahogy azt az általános szekunder kutatásnál is elmondhatjuk - nem minden esetben fedik egymást a szakértői vélemények és a kutatói célok. Ezt a módszert eredményesen alkalmazhatjuk az adott iparágra jellemző, különböző szakértői trendjelentések összevetésére, elemzésére.

A digitális korban a szekunder módszer speciális esete a (2) szakértői rendszerek vizsgálata, egyre gyakoribbá válik. A kutató a megfelelő hozzáférési jogosultságok birtokában rendszerint az adatbányászaton és adatelemzésen alapuló lekérdezéseket végez, majd az eredményeket feldolgozza, elemzi, értékeli, vagy már eleve a számítógépes program által feldolgozott ismeretet/tudást dolgozza fel saját szempontjai szerint. Sasvári (2012) a szakértői rendszereket az információs rendszerek egyik csoportjának tartja, s úgy vélekedik, hogy ,speciális, szük szakterü- 
leten hoz döntést vagy javasol megoldást nem strukturált problémák megoldására ... tényeket és szabályokat tárol, és ezek alapján következtetéseket von le". Bartha és Havasi (2011) Feigenbaum definícióját veszi alapul a szakértői rendszerekkel kapcsolatban, miszerint ,,a szakértői rendszer olyan számítógépes program, amelyik ismeretet (tudást) és következtetési módszert használ fel emberi szakértőket igénylő feladatok megoldására". Vagyis a szakértői rendszer a humán szakértő alternatívája lehet ezzel az aspektussal tanulmányomban nem foglalkozom. A továbbiakban a primer módszerek következnek.

(3) A személyes (és írásbeli) szakértői interjú, s a kutatás lebonyolítása leginkább az általános interjúhoz (Gordon - Langmaid, 1997) hasonlít, s a kvalitatív módszerek közé sorolható. Az általános interjúval ellentétben a szakértői személyes interjúról - az interjúalany engedélyével - minden esetben hang-, illetve videofelvételt célszerü készíteni annak érdekében, hogy a kutató a szakértői véleményt a lehető legteljesebb formában és tartalomban tudja feldolgozni, illetve újraközölni. Az általános (mély) interjú azon hátránya (Scipione, 1994), miszerint az eredmények tudományosan nem általánosíthatóak, a szakértői személyes interjúnál nem állja meg helyét, hiszen a szakértői kiválasztás során a kutató arra törekedett, hogy olyan szakember(eke)t válasszon ki, aki(k) véleménye markáns lehet a probléma megoldásában. Mivel „,a szakértői vélemények összegyüjtése vagy írásban történik, vagy szóbeli megkérdezésen alapul” (Nováky, 1999, p. 133.), ezért a kutatónak célszerü az interjút strukturált vagy félig strukturált formában megvalósítania, különösen akkor, ha több szakértőt is meg akar kérdezni. Ennél a módszernél (akár írásbeli, akár szóbeli) a szakértők nem feltétlenül ismerik meg egymást, illetve egymás véleményét, így a kutató külön-külön gyűjti össze, elemzi, s értékeli azokat. Az interjúalanyok száma rendszerint egynéhány szokott lenni.

A szakértői csoportos megkérdezésnél szóbeli és írásbeli megkérdezést különböztetünk meg. A módszerek többségénél a szakértők egymással interakcionálnak, $\mathrm{s}$ különösen a szóbeli csoportos megkérdezésnél az interakciók során alakítja ki a csoport a közös véleményét.

(4) A fókuszcsoportos szakértői megkérdezés leginkább az általános fókuszcsoportos megkérdezésre hasonlít (Gordon - Langmaid, 1997; Scipione, 1994). Mivel itt a csoport véleménye sokkal fontosabb az egyének véleményénél, így elég, ha a szakértők kiválasztásánál egyfajta minimumszintet határoz meg a kutató, vagy egy-két feladattal végez előszürést, hogy csak az azt sikeresen elvégzők lehessenek a csoport tagjai. A fókuszcsoportos szakértői megkérdezés történhet 8-12 fö, illetve minifókuszcsoport esetén 4-6 szakértő bevonásával. A csoport lehet a probléma vonatkozásában homogén (mindannyian hasonló állásponton vannak), de a kutató számára a téma alaposabb megismerését segíti elö, ha inkább heterogén (a szakértők többféle nézőpontot képviselnek). A szóbeli interjúhoz hasonlóan itt is célszerü hang-, illetve videofelvételt készíteni. A fókuszcsoportos beszélgetés ideje általában 90-120 perc, melyet nem érdemes szünettel megszakítani. A beszélgetést rendszerint bemutatkozással, majd a megvitatandó témákhoz illeszkedő ráhangoló kérdésekkel kezdjük. Ezek után kerül sor az egyes témák megvitatására, majd végezetül a (zárókörben a) - ha van - a konszenzusos és letisztult összegző vélemény megfogalmazására. A fókuszcsoportos szakértői megkérdezés során a kutató - föleg, ha úgy érzi, hogy a csoportdinamika egy kicsit alábbhagyott - az egyes témák után is tarthat összefoglaló köröket, amikor mindenki elmondhatja a témát záró körben az összegző gondolatait.

A jövőkutatással (pl.: Nováky, 1999), a kreativitást növelő módszerek alkalmazásával (pl.: Kindler et al., 1984, vagy Bono, 2007), illetve a döntéselmélettel (pl.: Paprika, 2002) foglalkozó szakirodalom számos olyan módszert nevez meg, illetve mutat be, amelyek a csoportos szakértői megkérdezés során is használatosak. Mivel ezek a nevezett szakirodalmakban megtalálhatók, ezért tanulmányomban csak összefoglalom a hozzájuk kapcsolódó fontosabb ismérveket. A technikákat szóban és írásban történő szakértői megkérdezés címke szerint csoportosítom. Az elsőbe tartozik többek között a brainstorming (ötletroham), a Philips 66, a nominális csoport módszer, a szinektika, a pro-contra módszer, illetve a hat kalap, míg a másodikba a brainwriting (ötletírás), a Rohrbach-féle 635-ös módszer, a szabad és az irányított asszociáció, a SEER-eljárás és a Delphi-módszer, mely utóbbi módszertanilag a később tárgyalt kérdőíves technikák közé is besorolható.

Az (5) ötletroham lényege, hogy a kutató az elözetesen meghatározott egy-néhány témát szeretné a szakértői csoportban ötletek, megoldási javaslatok segítségével körbejárni. Az ötletroham fontosabb szabályai a következők:

- a csak előzetesen meghatározott témákkal foglalkozhatnak a szakértők,

- tilos a résztvevők bírálata, bármilyen vad ötletet is mond valaki, azt is fel kell jegyezni,

- az ötletek feljegyzése mindenki által jól látható táblára történik,

- bátorítani kell a résztvevőket, hogy legyenek aktívak, merjenek bármilyen fantasztikusnak, hihetetlennek tünő ötletet is kimondani, megosztani, hiszen minden ötlet jó ötletnek számít,

- figyelni kell arra, hogy ne legyen olyan hangadó, aki miatt a többi tag elhallgat,

- a kimondott ötlet a csoporté lesz, azt egy másik csoporttag tovább gondolhatja, módosíthatja, összekapcsolhatja saját ötletével stb.

A szakmájában írásban kimagasló teljesítményt nyújtó, véleményével és igazolást nyert trendjeivel elismerést élvező szakértő nem biztos, hogy automatikusan jó lehet egy ötletrohamban történő részvételre. A maximum 1215 főből álló csoport akkor tud eredményesen müködni, ha a kutató mindenkit meg tud úgy szólítani, hogy az a személy végig a csoport aktív tagja maradjon. A kutató a csapatot az alábbi továbbfejlesztő, módosító kérdésekkel aktiválhatja (Kindler et al., 1984):

- „kik, miért, hogyan, kikkel, mivel?

- mi másra alkalmas?

- mihez hasonlítható? 
- ha egy kicsit módosítanám?

- hogyan tudnánk átalakítani, kijavítani, cserélni?"

- mi történne, ha egy kicsit megváltoztatnám valamely tulajdonságát?

- milyen más területeken lehetne még felhasználni?

- mire és milyen hatással lehet?

Az egy-másfél órás ötletroham végére ideális esetben a kutatónak nagyon sok ötlet, megoldási javaslat áll rendelkezésére. Ezeket vagy egymaga, vagy egy tapasztaltabb szakértő bevonásával értékeli, elrendezi (pl.: elmetérkép segítségével), így látható, hogy racionálisan mely javaslatok realizálhatók. Ha a kutató a témával tovább is szeretne foglalkozni, akkor a vad ötleteket külön gyüjti későbbi esetleges felhasználás céljából.

A (6) Philips 66 módszernél (VanGundy, 2008) a kutató több hat fös szakértői munkacsoportot hoz létre, melyek a téma és a nézőpontok szempontjából homogének vagy heterogének lehetnek (előzetes kérdőíves megkérdezéssel ez könnyen megszervezhető). A csoportok kötött időkeretben - 6 perc - az előzetesen definiált problémára választ keresnek. A csoportok egy-egy tagja a megbeszélés eredményét néhány gondolatban írásban összefoglalja, majd ezt a papírlapot átadja a kutatásvezetőnek. A gondolatok kiértékelése után az eredményeket ismertetik a csoportok tagjaival. A kutatásvezető direkt módon vagy véletlenszerüen újabb hat fös csoportokat alkot a szakértőkből, akik a probléma megoldásán tovább dolgoznak. A módszert akkor zárja a kutatás vezetője, amikor úgy érzi, hogy a csoportok kifogytak az ötletekből. Ilyenkor már rendszerint egy letisztult, célravezető megoldás jelenik meg a vélemények között, így az ötletrohammal ellentétben az eredmények sokkal könnyebben és gyorsabban prezentálhatók a kutatási jelentésben.

A (7) pro-contra interakcióban ,a 10-15 fös csoport a különböző kreatív metodikákkal kidolgozott megoldási variációkat, elképzeléseket, feltárt hatótényezőket, stb. minősít, értékel” (Kindler, 1984, p. 75.). A különböző megoldásoknál két fő védő, két fő pedig támadó álláspontra helyezkedik, a csoport többi tagja pedig az elhangzó pro és kontra érvek segítségével alakítja ki a véleményét. Kb. 15 perc után szerepcsere történik: a védőkből támadók, a támadókból védők lesznek. A csoport ezeket az álláspontokat is meghallgatja, majd kialakítja végső, letisztult, érvekkel alátámasztott véleményét. Az érveket és ellenérveket a későbbi feldolgozás érdekében célszerü táblán/faliíven rögzíteni.

Ha a kutató a (8) nominális csoport módszert (NCM) (Tracy, 2015) választja, akkor először megkéri a szakértőket (a hatékonyság szempontjából maximum kilenc főt), hogy írják le egymás jelenlétében a problémával kapcsolatos elképzeléseiket, álláspontjukat, véleményüket, majd ezeket körbenjáró módon ismertetik, s a csoporttagok megvitatják. A csoport eldönti, hogy a problémát mely tényezők idézik elö, vagy mely megoldási elképzelések oldják meg (NCM értékelö lapon pontozzák az egyes elképzeléseket). Kezdő kutatók számára ez egy viszonylag nehéz csoportos szakértői megkérdezéses módszer.

A (9) szinektika módszer alkalmazásakor ,5-7 magasan képzett, alkotó típusú szakembert egy hosszabb idejű
- gyakran egy év - módszertani-szakmai képzésben részesítenek és ők vesznek részt a szakértői megbeszéléseken" (Nováky, 1999, p. 138.). A gyakorlatban a szinektika módszerét lehet alkalmazni olyan (másoddiplomás) egyetemi hallgatók megkérdezésénél is, akik a szakválasztást követően csak az adott szakhoz illeszkedő speciális tantárgyakat tanulnak, szakirányt, specializációt választottak, s megfelelnek a kutató szakértői minősítésének (junior szakértőkből álló csoport). Öket akkor tekinthetjük szakértőnek, ha (akár fiatal koruk ellenére is) több éves szakmai tapasztalattal rendelkeznek az adott területen, azt tanulmányaikból jól ismerik, tudásukat sikeresen mérettették meg szakmai versenyeken, előzetes ismereteiket a kutatás vezetője önkitöltős kérdőívvel és/vagy egyéb módon ellenőrizte. A gyakorlatban ezt a módszert választottuk (Haig - Kollár, 2017, illetve Kollár - Ványa, 2017) a Nemzeti Közszolgálati Egyetem végzős, válogatott és előszürt hallgatóinak az információbiztonság, illetve az ember-robot interakció témáival kapcsolatban folytatott szakértői megkérdezése során. A csoportos szóbeli beszélgetéseket megelőzően a megkérdezettek az elöfeladatokat otthon sikeresen elvégezték, a tanult ismeretek felelevenítették és két gyakorló, tapasztalt szakember, mint kutatásvezető irányításával folytattak egymással irányított szakmai beszélgetést a fókuszcsoportban.

Bono (2007) (10) hat kalap módszere a vitatkozás, az eltérő gondolatok ütköztetése helyett a párhuzamos gondolkodásra fókuszál. A kutató előzetesen hat szakértőt választ ki, majd a személyes csoportos beszélgetés során arra kéri öket, hogy miután ismertette a problémát, illetve az esetleges megoldási elképzeléseket, mindenki vegyen fel egy színes kalapot. Az adott színes kalap egy bizonyos szerepet testesít meg, úgymint: fehér - tények, piros - érzések, fekete - ellenvetések, sárga - elönyök, zöld - ötletek, kék - folyamat. A kalapokat több körön keresztül cserélik mindaddig, amíg mindenkire legalább egyszer nem került valamelyik kalap. Ideális esetben - mivel valamennyi szakértő valamennyi szerepben látta a problémát - egy konszenzuson alapuló, nagyon markáns megoldási javaslat(sor) születhet.

Az írásban történő szakértői megkérdezés alapmódszerének az (11) ötletírást tekintjük (Nováky, 1999), amikor a szakértők írásban juttatják el egymáshoz a javaslataikat. A javaslatokat továbbgondolják, kiegészítik, majd a kutatás vezetője az ötletrohamnál leírtak szerint elemzi és értékeli azokat. Mivel itt nem lehet beszélni igazi interakcióról, ezért az alapmódszert továbbgondolták (pl.: szabad irányított asszociációk, 635 módszer).

A (12) szabad és irányitott asszociációknál a kutatás vezetője arra kéri a szakértőket, hogy a többi szakértőtől írásban megkapott ötleteket vagy szabad, vagy meghatározott szempontok szerinti asszociációk segítségével egészítse ki.

A (13) Rohrbach-féle 635 módszer (Kindler et al., 1984) lényege, hogy miután a kutatás vezetője ismertette a problémát, a hat fös szakértői csoport valamennyi tagja az elöre elkészített vélemény- és ötletgyüjtő lapon három-három javaslatot, ötletet, elképzelést ír le. Ezeknek a papírlapoknak a tartalmát aztán a többi csoporttag is megismeri, akik ezek alapján az ötleteket továbbfejlesztik, kiegészítik, továbbgondolják, illetve új elképzelésekkel gazdagítják. A módszerben összesen hat ilyen forduló van. Egy fordulóban 
$3 * 6=18$, a hat forduló során pedig $6 * 18=108$ megoldási javaslat, ötlet, elképzelés stb. születik. Az első forduló időkerete 5 perc, a többié rendszerint 6-7 perc. Az összegyüjtött 108 lap tartalmát a kutató vagy saját maga, vagy egy tapasztaltabb szakértővel közösen kiértékeli, rangsorolja, esetleg különböző csoportokba helyezi, majd ennek alapján alkotja meg a kutatási jelentést.

A (14) Delphi-módszer (Stewart - Shamdasani, 2015) alkalmazása során a szakértők több kérdőívet töltenek ki. Először átfogó kérdésekre válaszolnak (ez hasonlatos a többi módszernél említett szakértői előszűréshez), majd a kapott válaszok alapján a kutatás vezetője elkészíti a második kérdőívet, amit a szakértők ismét kitöltenek, majd ezt a folyamatot addig ismétlik, amíg a résztvevők között az adott probléma megoldását illetően konszenzus alakul ki, illetve megfelelő számú és minőségü elképzelés cserélődött a csoporttagok között.

A (15) ,SEER-módszer lebonyolitása két fázisban történik" (Nováky, 1999, p. 145.). Az első fázisban a kutatás vezetője, vagy az általa felkért szakember az (1) pontban bemutatott szekunder elemzés módszerével előrejelzést készít vagy összefoglalja egy rövidebb jelentésben ezeket az elképzeléseket. A jelentést elküldik a több szakértőnek, s arra kérik őket, hogy egészítsék ki, véleményezzék, értékeljék az egyes elképzelések fontosságát, állítsanak fel ennek alapján rangsort, illetve trendelemzésnél becsüljék meg az egyes események bekövetkezési valószínüségét. A második fázisban rendszerint újabb szakértőket kérnek fel arra, hogy az előző szakértők véleményeit megismerve, egy személyes találkozás alkalmával vitassák meg az elképzelésüket, illetve rajzolják meg a SEER-fát, amin jól láthatók hosszú, közép- és rövid távon a célok, a szükséges és a kívánatos feltételek. A SEER-fa, valamint az elemzések alapján tudja a kutató elkészíteni a jelentését, melyben kitérhet a múlt-jelen-jövő viszonyára is.

Megjegyzem, hogy a csoportos szakértői megkérdezésből készített kutatási jelentésben érdemes a csoport bemutatásánál kitérni a demográfiai, iskolázottsági és munkatapasztalatokra, vagyis többek között az életkorra, a nemre, a legmagasabb iskolai végzettségre, az adott területen szerzett tapasztalatra (évek), a szakértői minősítésekre, díjakra. Ezek az impresszív elemek nagyobb hangsúlyt és markánsabb alapot adnak a kutatási jelentésnek.

Az ötletek, elképzelések, vélemények mint textuális tartalmak szakértői értékelése mellett célszerü kitérni arra is, hogy a társadalom- és bölcsészettudományi (pl.: szociológia, antropológia), valamint a rendészettudományi és biztonságtudományi területeken álló és mozgókép-, illetve hangtartalmakkal is találkozhatnak a szakértők. Az (16) álló- és mozgóképelemzés, illetve hangfájlelemzés körébe tartozó videográfia és fotóinterjú (Horváth - Mitev, 2015) szakértői elemzése kiegészül többek között az írásképek grafológiai elemzésével, a vizuális szociológia módszereivel, az álló- és mozgóképtartalmak eseményeinek, hőtérképének elemzésével, a szereplők arcának, hangjának felismerésével és beazonosításával is. Ilyenkor - a müszaki és orvostudományi szakértői tevékenységhez hasonlóan - rendszerint egy-néhány szakértő véleménye, illetve két szakértő eltérő véleménye esetén harmadik szakértő bevonásával alakul ki a közös álláspont.
Az (17) irásbeli szakértői kérdőives megkérdezés (Bogner - Littig - Menz, 2009) abban tér el az általános kérdőívtől, hogy a szokásos demográfiai kérdések mellett (pl.: nem, életkor, legmagasabb iskolai végzettség) a szakértőknek több adatot kell megadniuk magukról, többek között azt, hogy milyen területen szerzett felsőfokú végzettséget, milyen szakon/szakirányon, valamint szakmai konferenciákon való részvétel gyakorisága, szakmai továbbképzéseken való részvétel gyakorisága, szakmai tapasztalat területeken és években, mennyire követi a törvényi szabályozást, munkahely, munkakör, szakmai díjak és elismerések, szakmai szövetségi tagságok, külföldi tanulmányutak, rendszeresen olvasott nyomtatott és elektronikus szakirodalom, illetve hírlevelek és egyéb online csatornák (pl.: Linkedin/Facebook), szakmai minősítések, előadások tartása (pl.: egyetemen, konferencián, belső tréningen), publikációs aktivitás, médiaszereplés (nem celeb!), önértékelés (pl.: ötfokú skálán) a vizsgált témához tartozó területen és/vagy szakmai kompetenciákban. Az így megszerzett - önbevalláson alapuló - adatok többféle módon dolgozhatók fel. Egyszerü esetben - rendszerint a leíró statisztika részeként - bemutatják a vizsgált sokaságot, esetleg megrajzolnak néhány kereszttáblát és kiszámolnak néhány korrelációs együtthatót. Szofisztikáltabb vizsgálat során a kérdöív önbevallásos részénél kapott adatokra építve valamilyen algoritmus alapján például egy fótéma-kompetenciát határoznak meg százalékos alapon, majd a kapott válaszok kiértékelése során ennek alapján súlyozást végeznek. Az $n=\left(\frac{\sigma * z}{D}\right)^{2}$ képlet alapján, ha a pontosság: $\mathrm{D}= \pm 5 \%$, a megbízhatósági szint: $\mathrm{CL}=95 \%$, a megbízhatósági szinthez tartozó érték: $Z=1,96$, a $\sigma=50$ 55 között van (esetünkben 50), akkor $n=\left(\frac{50 * 1,96}{5}\right)^{2} 385$ fö szakértő (pl.: szakmai kamara szakértői körében végzett kérdőíves megkérdezés) véleménye már statisztikai értelemben is reprezentatívnak tekinthető. Megjegyzem, hogy szakértői megkérdezés esetén hiba, ha a kutató a reprezentativitás idolát keresi. Azzal, hogy kellő szakértelemmel és gondossággal választotta ki a vizsgált terület akár csak egy-néhány szakértőjét is, olyan tudást, tapasztalatot és bölcsességet vont be a vizsgálatba, aminek révén a szakértői vélemény minőségében egyértelmüen felülmúlhatja a többszáz ,általános” válaszadó véleményét.

\section{Záró gondolatok}

A tudományos megismerés, ismeretalkotás és -közlés (Tomcsányi, 2000) módszerei között a szakértői megkérdezés, illetve a szakértői megkérdezés során kapott válaszokból alkotott eredmények felhasználása meghatározó szerepet tölt be. Ennek több oka van.

Az előnyök között említhető, hogy a szakértői megkérdezéssel - a felkészült kutató a megfelelő módszer használata mellett - a kvantitatív módszerek többségéhez viszonyítva gyorsabban juthat eredményre, mivel a szakértői vélemények (föleg, ha azok konszenzuson alapulnak) akár komolyabb átalakítás nélkül is beemelhetők a kutatási jelentésbe. Számos olyan téma/probléma van, aminél a szakértői megkérdezés bizonyul a leghatékonyabb módszernek, mert más módszerekkel a probléma vagy nem vizsgálható, vagy a ka- 
pott eredmények csak megszorításokkal és fenntartásokkal értelmezhetők. Természetesen az átlagembernek is lehet felhasználható és értelmezhető véleménye, de a probléma komplexitásából adódóan szükség van az átlagemberhez viszonyított magasabb elméleti és gyakorlati ismeretekkel rendelkező személyek bevonására a téma vizsgálatához. Ha a szakértő kiválasztása kellő körültekintéssel történt, akkor a kapott eredmények rávetíthetők akár egy teljes sokaságra is, ellenben egy átlagos válaszadókból álló fókuszcsoport, interjú, illetve kérdőív módszerével, melyeknél a kapott eredmények rendszerint csak jelzésértékkel bírnak, vagy csak bizonyos fenntartásokkal, meghatározott megbízhatósági szinten és pontosság mellett fogadhatók el. Összetett, többaspektusú problémák kérdőíves elemzésénél nem vezet jobb eredményre az sem, ha a válaszadók számát a kutató megnöveli annak érdekében, hogy a nagyobb minta révén statisztikai értelemben növelje a pontosságot és a megbízhatóságot. A szakértők felkérése és megkérdezése a kutatásokban rendszerint költségcsökkentő tényezö lehet, föleg, ha a szakértők a tudomány iránti elkötelezettségükből adódóan önkéntes alapon, ellenszolgáltatás nélkül vesznek részt a kutatásban. Vállalati környezetben pedig a néhány szakértő szakmai állásfoglalásáért fizetett díj rendszerint alacsonyabb lehet egy többszáz fó megkérdezésével megvalósított kérdőíves kutatáshoz képest, fóleg, ha a kutatásba alvállalkozót, kérdezőbiztosokat, a statisztikai módszerekhez értő szakembereket, esetleg drága statisztikai szoftvereket is be kell vonni.

Bár számos érv szól a szakértői megkérdezés mellett, a téma objektív zárása megkívánja a hátrányok megnevezését is. Egységes módszer (kvázi ajánlás) nincs arra vonatkozóan, hogy a kutató milyen szempontok szerint minősítse azokat a résztvevőket, akiket szakértői minőségben von be a vizsgálatba. A szempontok kialakításánál hagyatkozhat az általa vizsgált területen tevékenykedő szakmai szervezetek szakértői kiválasztási/minősítő rendszerére, jogszabályi leírásokra, szakmai ajánlásokra, vagy neves szakértő véleményére. Ugyancsak nem lehet egyértelmüen meghatározni, hogy a kutatói szakértőminősítés során az egyes tényezők mekkora súllyal szerepeljenek. Nem minden esetben lehet meghatározni a kutatásba bevont szakértők elégséges létszámát, illetve az is előfordulhat, hogy nem áll rendelkezésre megfelelő létszámban szakértő. A bemutatott módszerek többségénél a módszerek kidolgozói ajánlást tesznek a résztvevők számára, illetve Nováky (1999, p. 133.) megjegyzi, hogy „megbízható elörejelzés készítésénél mintegy 30-50 fös szakértői csoport adhat megfelelő menynyiségű és minőségű becslést." Ugyanakkor hozzáteszi, hogy ,ilyen jelentős létszámú szakértői gárda összeállítása ... az esetek egy részében gondot okozhat, hiszen előfordulhat, hogy a témának nincs is ennyi szakértője.” Bár a szakértőtől elsősorban nem empatikus és érzelemvezérelt müködést várnak el, a szakértő technokrata feladatcentrikussága a probléma optimális megoldásának folyamatát túl merevvé teszi, esetleg károsan befolyásolja a csoportban végzett szakértői tevékenységet is. Hátrányként említhetô az is, hogy ugyan több módszer is rendelkezésre áll a szakértői előrejelzések megbízhatóságának az értékelésére (Nováky, 1999), a hasznosság és hasznosulás tekintetében nem található jól alkalmazható ROI (Return on Investment, befektetés megtérülés), illetve KPI (Key Performance Indicator, kulcs teljesítménymutató) módszertan. Ez azt jelenti, hogy elsősorban a kutató/megbízó szakmai igényességén és a kiválasztási módszertanban való jártasságán múlik, hogy olyan szakértőket vonjon be a kutatásba, döntéstámogatásba, prognosztikába stb. akinek a szakértelme témareleváns.

Az egyéni és csoportos szakértői megkérdezés során a kutató bátran dolgozhat ki új módszereket, melyek vagy az itt is bemutatott módszerek továbbfejlesztett változatai, vagy azoktól merőben eltérőek. Ha a szakértők kiválasztását, illetve megkérdezését logikus és érvekkel támogatható gondolatfolyam mentén tervezik és valósítják meg, akkor a kapott eredményeknek is meg kell felelniük a kutatásmódszertani kívánalmaknak.

A szakértők kiválasztásánál az életkor és a szakmai-gyakorlati tapasztalat rendszerint fontos tényező. Vannak azonban olyan nem is mindig speciálisnak mondható területek, ahol a kimondottan fiatal, a pályájuk elején álló, vagy még tanuló válaszadókra tekint a kutató szakértőként. Ilyen terület többek között a közösségi média, az információbiztonság és a hackerkultúra, illetve a fiatalok körében népszerü müszaki-technikai fejlesztések. Ezeknél rendszerint a(z egyetemen) és az interneten tanult elméleti-gyakorlati ismeretek és az eszközök, alkalmazások használata során szerzett alapos személyes és csoportos tapasztalat ideális ötvözete biztosíthatja a kutatónak azt a szemiotikai keretet és biztonságot, amiben a szakértő fogalmát használhatja.

Tanulmányomban zömében a hagyományos, fizikai világban realizálható szakértői megkérdezés módszereit mutattam be. A digitális kor által nyújtott platformokon azonban hasonló hatékonysággal és eredményességgel lehet megszervezni és lebonyolítani a szakértők kiválasztását (pl.: digitális szakmai lábnyom, online szakértői adatbázisok) és megkérdezését (pl.: chates interjú és fókuszcsoport, online kérdőív, a csoportos munkát lehetővé tevő online dokumentumkezelő rendszerek).

Végezetül szeretném megjegyezni, hogy a szakértő (még ha csoportban dolgozik) is tévedhet. A kutatónak/ megbízónak tudatában kell ennek lennie, s a szakértő és véleményének fetisizálása helyett az objektív elfogadás és megismerés, az akár kritikai észrevételek megfogalmazása a javasolt magatartás.

\section{Felhasznált irodalom}

Ábrahám Z. - Eörsi M. (2003): Pereskedni rossz! - Mediáció: a szelíd konfliktuskezelés. Budapest: Minerva Kiadó

Arthur, K. (2012): Mind Mapping: Improve Memory, Concentration, Communication, Organization, Creativity, and Time Management. Hillside, IL: Book Stream Publishing

Babbie, E. (2000): A társadalomtudományi kutatás gyakorlata. Budapest: Balassi Kiadó

Bagdy E. - Wiesner E. (2005): Szupervízió: Egyén - csoport - szervezet. Budapest: Printx Budavár

Bartha G. - Havasi I. (2011): Térinformatikai alapismeretek. Miskolc: Miskolci Egyetem 
Block, P. (2005): Makulátlan tanácsadás. Budapest: HVG

Bogner, A. - Littig, B. (2014): Interviews mit Experten: Eine praxisorientierte Einführung (Qualitative Sozialforschung). Berlin: Springer

Bogner, A. - Littig, B. - Menz, W. (2009): Interviewing Experts. Hampshire: Palgrave Macmillan

Bono, E. (2007): A hat gondolkodó kalap. Budapest: Manager Könyvkiadó

Csemáné Váradi E. - Gilányi E. (2011): Alternatív vitarendezés. Budapest: Nemzeti Tankönyvkiadó

Dürrschmidt, P. - Koblitz, J. - Mencke, M. - Rolofs, A. - Rump, K. - Schramm, S. - Strasmann, J. (2008): Trénerek kézikönyve. Miskolc: Z-Press Kiadó

Fejes J. (2015): A tudásmenedzsment fejlődési szakaszainak tettenérése a magyar üzleti tanácsadás piacán. Vezetéstudomány, XLVI. évf. 8. szám, p. 24-75.

Gordon, W. - Langmaid, R. (1997): Kvalitatív piackutatás. Budapest: HVG

Hengl M. (2015): Szakértés, szakvélemény, szakértő, (gazdasági) bünügyek. Büntetőjogi Szemle, 1-2. szám, p. 50-53.

Hess, D. J. (1997): Science Studies: An Advanced Introduction. New York: NYU Press

Holliday M. (2001): Coaching, Mentoring and Managing. Wayne: Careerpress

Horváth D. - Mitev A. (2015): Alternatív kvalitatív kutatási kézikönyv. Budapest: Alinea Kiadó

Ivlev, I. - Kneppo, P. - Barták, M. (2015): Method for selecting expert groups and determining the importance of experts' judgments for the purpose of managerial decision-making tasks in health system. Ekonomika a Management, XVIII. évf. 2. szám, p. 57-72.

Kádi A. (2016): A szervezeti kockázatvállalás és sikeresség kapcsolata a szervezetpszichológia nézőpontjából. Vezetéstudomány, XLVII. évf. 7. szám, p. 14-28.

Kaner, S. (2014): Facilitator's Guide to Participatory Decision-Making. San Francisco: Jossey-Bass.

Kaweh, B. (2017): Coaching kézikönyv - Coachoknak és oktatóknak. Budapest: Bioenergetic Kiadó

Kelló É. (szerk.) (2014): Coaching alapok és irányzatok. Budapest: Akadémiai Kiadó

Kindler J. - Klein S. - Papp O. - Tibay Gy. (1984): A kreativitást növelö módszerek alkalmazása. Budapest: BME

Krippendorff, K. (1995): A tartalomelemzés módszertanának alapjai. Budapest: Balassi Kiadó

Langer, K. (2009): Kvalitatív kutatási technikák. Gödöllö: Szent István Egyetemi Kiadó

Malhotra, N. K. (2002): Marketingkutatás. Budapest: KJK Kerszöv

Mérei F. (2006): Közösségek rejtett hálózata. Budapest: Osiris Kiadó

Nováky E. (1999): Jövőkutatás. Budapest: AULA

Poór J. (2016): Menedzsment-tanácsadási kézikönyv. Innováció - megújulás - fenntarthatóság. Budapest: Akadémiai Kiadó

Sasvári P. (2012): Az információs rendszerek kisvállalati alkalmazásának vizsgálata. Vezetéstudomány, XLIII. évf. különszám, p. 56-65.
Scipione, P. A. (1994): A piackutatás gyakorlata. Budapest: Springer Hungarica

Stewart, D. W. - Shamdasani, P. N. (2015): Focus Groups, Theory and Practice. Thousand Oaks: SAGE Publications

Strasser, F. - Randolph, P. (2008): Mediáció - A konfliktusmegoldás lélektana. Budapest: Nyitott Könyvmühely Kiadó

Tokár-Szadai Á. (2013): Tanácsadói szerepek, kompetenciák. Vezetéstudomány, XLIV. évf. 3. szám, p. 26-36.

Tokár-Szadai Á. (2017): A vezetési tanácsadók kiválasztásának szempontjai. Vezetéstudomány, XLVIII. évf. 6 -7. szám, p. 39-48.

Tomcsányi P. (2000): Általános kutatásmódszertan. Az ismeretalkotás és -közlés tudományszaktól független elmélete és gyakorlata. Budapest: OMMI

Tönnes, F. (2004): Közösség és társadalom. Budapest: FOK-TA BT.

Tracy, B. (2015): Creativity \& problem solving. New York: AMACOM

VanGundy, A. B. (2008): 101 Activities for Teaching Creativity and Problem Solving. San Francisco: Pfeiffer

Vogelauer, W. (2002): A coaching módszertani ABC-je. Budapest: KJK Kerszöv

Vogelauer, W. (2002): Coaching a gyakorlatban. Budapest: KJK Kerszöv

Wehrle, M. (2014): Az 500 legjobb coaching-kérdés. Budapest: Garbo Könyvkiadó

Wundt, W. (1898): Grundriss der Psychologie. Lipcse: Verlag von Wilhelm Engelmann

Z. Karvalics L. (2015): Az abduktív menedzsmenttől a tudáskormányzásig. Vezetéstudomány, XLVI. évf. 6. szám, p. 12-21.

Zelina Gy. (2013): Mesterségem címere: Coach. Budapest: Andalúz Kiadó és Dekameron Kiadó

\section{Elemzésbe vont fontosabb források}

Bankárképző tanulmányi- és vizsgaszabályzata a képesített compliance szakértő képzéshez: https://www. bankarkepzo.hu/images/files/2017/Tanulm\%C3\%A1nyi_\%C3\%A9s_Vizsgaszab\%C3\%A1lyzat/tanulmanyi_es_vizsgaszabalyzat_KCO_szakerto_2017. pdf

Grafológusok és Írásszakértők Országos Szövetsége http://www.grafologirsz.hu/index.php?option=com content\&task=view\&id=147\&Itemid=83

Igazságügyi Szakértői és Kutató Intézetek http://www. iszki.gov.hu/

Nemzetbiztonsági Szakszolgálat http://www.nbsz.gov. $\mathrm{hu} /$ ? $\mathrm{mid}=18$

Nemzeti Szakértői és Kutató Központ http://nszkk.gov. $\mathrm{hu} /$

Nemzeti Szakképzési és Felnőttképzési Hivatal Országos Képzési Jegyzéke: https://www.nive.hu/index. php?option $=$ com_content\&view $=$ article \&id $=297$

Országos Írásszakértő Intézet http://www.irasszak.hu/ kepzesfajtak.php\#irasszakerto_kepzes

Szociális portál www.szocialisportal.hu 